\title{
THE PLAYGROUND AS A FACTOR IN SCHOOL HYGIENE.
}

\author{
By George E. Johnson, \\ Superintendent of Playground Association, Pittsburgh, Pa.
}

Scarcely twelve months ago the whole country was shocked by a disaster to school children so horrible in its details that men in distant cities wept in street-cars as they read the account in the morning papers. Immediately, everywhere, school buildings were inspected and hundreds of thousands of dollars were expended in alterations and fire escapes.

Since then, in the city of that sad disaster, and in every city of equal size, many times that number of children have perished and scarcely a comment has been raised. It would take four disasters like that at Cleveland every school day in the year to keep pace with the march of death among the school children of our land.

During the coming year more than one hundred thousand school children will end their young lives, the bloom of babyhood scarcely yet faded from their cheeks, and tens of thousands of Rachels will mourn for their little ones and not be comforted.

During the next ten years millions more will lay the foundation of weak constitutions to succumb to some great white, black, red or yellow plague before life's meridian has been reached.

To those who rejoice in the living, Dr. Hutchinson's cheering declaration that "it isn't so very dangerous to be alive" will bring its reassurance, but to those who mourn for the dead, it will lend an added pathos. The unnecessary loss is the hardest to bear. And this loss, ineonceiveably great as it is, is largely within our power to prevent. For not only is it not so very dangerous for a child from five to fifteen to be alive, it is the natural and easy thing for him to remain alive,-if he has a fair chance.

These are the years when the life forces are at flood. It is as if Nature endeavored to repeat in each young life at this age the observance of the Passover and had sprinkled upon the gate posts of these ten hopeful years the sign of immunity that the Angel of Death seeing might pass by. We school men often con- 
gratulate ourselves that the years which constitute the school age for the great majority of children are the years when the death rate is the lowest. And yet the aggregate preventable loss through death, in these most favored years, is enormous, and the sad processions that follow abandoned hopes to the grave outnumber in the aggregate the armies of the world.

But there is another and far more serious loss than this. It is not the death rate during the school age, however great or small, that is the significant thing for us. The significant thing is whether in these years of Nature's smiles, strength or weakness is being laid by for future years. We are learning more and more certainly every year that our skulking foe, the microbe, of whatever tribe, strikes when a man is down. Patiently he bides his time, gathering his forces in secret until the time to strike. No better illustration could be given than that of tuberculosis. According to Newsholme, only three children in ten thousand, from five to fifteen years of age, die of consumption, but from fifteen to forty-five more than one person in four dies of this dread disease. Speaking along this line, Dr. Tyler says: "It would seem highly probable that the increased deathrate of girls at eighteen and thereabout from consumption and other diseases of relatively slow action is the culmination of an attack begun at thirteen or fourteen. If we are to diminish this death-rate, we must fortify the girl against the periods of greatest weakness when she is most likely to receive hospitably the germs of fatal diseases. To accomplish this we must not wait until the twelfth or thirteenth year, but meet the difficulty in childhood." Huber, also, in his work on "Consumption" says: "There is the long period of latency in which, if the child be well nurtured and if he live hygienically, he will be likely to overcome such tendency to disease as he may have begun life with."

When at some future time posterity looks back upon the conditions that prevail in our day, it will behold no darker picture, no more disgraceful thing than our weak surrender of our children to sickness and death. What excuse can then be offered for the fact that even in this land, more than one-half of all the children born into the world die before they have reached man's estate; that seventy per cent of school children suffer some physical handicap, more or less serious, at the very threshold of life's opportunities; that our schools not only do not fortify the children against known enemies, but actually betray them, in their innocence, to their deadly foes? 
To the American School Hygiene Association belongs the great credit of an organized effort to free us from this national error, but may I present the humble claim that the advocates of the playground offer the most promising single means for its accomplishment?

From amœba to man the essential conditions to life and health have been few and plain. Through all the ages of that slow ascent, but with varying emphasis, these have been food, air, sunshine, exercise. Upon the supply of these in proper kind and amount depends the health of amœba, worm, fish, bird, dog or man.

Omitting the first of these for obvious reasons, let us consider the importance of each of the others in school hygiene and the office of the playground in supplying them.

Air. The playground is the only place where a school child gets air in the proper amount and kind, the only place where he obtains full and complete aeration of the blood. A despicable fraction of school rooms have standard ventilating apparatus, and the rooms that have do not always adequately benefit thereby. I have personally tested a score of school rooms almost under the shadow of the capitol of a state that has the best of existing laws, and found the supply of air to equal the standard in only two of the rooms and in some it fell to less than one-fourth of that amount.

But even could ventilation be perfect in a school room, there would not be the same aeration of the blood in a seated studying child as in a child on the playground. There must be the exhilaration of joyous exercise, the strengthened pulse, the quickened, deepened breathing, the full chest of sustained effort that drives the air to the very apexes of the lungs, to meet the needs of the growing child. The school room may be made less and less objectionable, but so long as it remains a school room it can not escape the imperative need of the playground as a factor in school hygiene.

As is well known, it is not only the lack of oxygen but also the presence of organic poison in exhaled air that makes ventilation so important. It is a fact noted by biologists that all animal life excretes a poison destructive to itself. This is as true of the singlecelled animal as of higher life. Bacteria may thrive luxuriantly for a time in culture media, but if they are not transferred to fresh culture media they pass into a period of lessened activity and finally die poisoned by their own excretions. A child's body is an accumulation of a vast number of cells, each of which by its very functional activity likewise excretes products so poisonous to itself 
and the system generally, that accumulation beyond a certain limit results in death.

Now nature has gradually placed more and more emphasis upon this cleansing process. If you trace the evolution of the vital organs from the single cell to man, you will find a general increase in the number of the excretory organs. The newer organs have developed as supplementary to the older, and all together they form a coöperative system, a weakness in any part of which places an added burden on the rest. Nature here gives us no uncertain hint as to the needs of the child. Playground activities not only purify the blood through the increased activity of the lungs in the pure air of out-of-doors, as the activites of the school cannot do, but also stimulate the healthful activity of all the excretory organs, preserving a well balanced system.

Sunshine. "Where the sun does not go, the doctor does" is an Italian proverb quoted by Koetelmann. Try as we may, we can not get the sun sufficiently into all our school rooms, and if we could we would shut it out again as soon as we let the children in to study, because we say it hurts their eyes.

Where then shall the children bathe in the sunshine as they should, but on the playground? We do well to debar contagious diseases from the schools, but let myraids of bacilli fly over our children's clothing and the most malignant perish in a short time in the joy and the sunshine of the playground. Few disease germs have been discovered that can survive even for one hour the streaming sun on the face of a laughing child.

You remember the experiment with the tadpoles. They were placed away from the sunlight for thirty days and during all that time ceased to grow. Returned to the sunlight, they resumed their growth and advanced farther in one day than in all the previous thirty. Placed once more away from the sunlight and again returned to normal conditions, they grew to stunted froghood. Just such an experiment, Society tried with babies in the dark rooms of New York's tenements, and every baby, almost without exception, born and kept in those rooms, died. But when Jacob Riis tore down the windowless walls and the light of Heaven streamed in, the babies began to live.

In our cities and larger towns everywhere, we are still repeating, in a measure, the same experiment, and place our children, like the unfortunate tadpoles, in darkened homes, in narrow, shaded, and smoke-enveloped alleys, and in school rooms into which the sun seldom if ever enters, - nay! often in school rooms lit 
even in the middle of the day by natural or artificial gas. Bring to these little ones medical inspection, examine their eyes, remove their adenoids, protect them from measles and all the rest, but shall we not also provide a playground, where for a part of the day they may bathe in the sun as God Almighty has said they must, if they are to live!

Exercise. I have just examined the indexes of two famous books on school hygiene and in them was no such word as exercise. But exercise is life, and the absence of it is the sure sign of death. By exercise came evolution. Exercise shaped the body, determined the vital organs, built the brain. By exercise the child takes possession of his inheritance from the race. To him it is the past, the present, and the promise of the future.

But that exercise no man can dictate, no teacher devise, no scholar fully define. It comes forth unbidden from the child, declares his nature, discovers him to himself, defines his relation to his mates, shows him the world. Itwis his play, it is himself. Can the school alone do this, be this? In the long process in which exercise shaped the body and built the brain, there was determined for all time the path by which the child must come into his own. In that shortened process we call childhood, every faculty, every power, every organ that fails to receive its due exercise shrivels, and health by so much suffers and by so much the man becomes less a man. It would require a book to speak in full of the exercises of the playground that meet the needs of health, physical, mental, moral, æsthetic, social health, for all these are elements in the health of the body, as we all have come to understand. But in many respects, in the very nature of the case, these exercises are impossible in the school, they are possible only on the playground.

Once upon a time the people of a certain city really believed what I have just been trying to say, and when the question arose as to whether they should build a great public school or open a playground, it was decided to open a playground. Now it came to pass, in the course of years, that the citizens of that city advanced so far beyond the rest of the human race, that, in all the centuries since, the nations that have gone on building public schools and neglecting to open playgrounds have not been able to catch up with them even to this day.

This is fact, not fancy. At seven years of age the Athenian lad entered the palaestra, which was essentially a playground. All the first and better half of the day was spent in gymnastics, dancing, games and play. In the afternoon there was singing, some 
writing (the beginners wrote in the sand box or in sand strewn upon the ground), some reading, all in the open air, and then came a long period of play again. Such was the schooling of the Greek lad up to the age of ten or eleven and it did not differ essentially up to the age of sixteen except in the severity of the exercises. And yet, the world has not ceased to marvel at the results of the Greek education. It produced the highest type of man, physically and intellectually, that the world has ever seen, which Galton says was as far in advance of the modern Englishman as the modern Englishman is in advance of the native African. In physical beauty, courage and patriotism, in philosophy, literature, architecture and art, the Greeks have been the unsurpassed models of the ages and are still the inspiration of our schools to-day. But they placed the emphasis upon hygiene, exercise, games and play, which we neglect, if not ignore. They cared for the strong and sometimes left the weak to perish. We care tenderly for the weak and often leave the strong to perish.

This also is fact, not fancy. In the state where I had the privilege of acquiring most of my experience in educational work, a child to obtain the best educational advantages must be blind, deaf, feeble-minded, incorrigible or a truant. Then he is given exercise, playgrounds, gymnasia, baths, fresh air in abundance, gardens and play-shops. The great majority of normal children get along the best they can without them. And now in Pittsburgh they have an open-air school for children with a tendency to tuberculosis. So consumption seems to be another of the list of ills, one of which a child must have in order to enjoy the best educational advantages. I am not disapproving of this care for the weak. I believe in it with all my heart, but this we should have done and not left the other undone. There are thousands and thousands of children in the regular schools of Pittsburgh who have no place to play, no recess, no really fresh air to breathe, little sunshine and less genuine life-giving exercise.

We have reversed the order of importance in education as it was observed by the Greeks. The Greek education was essentially a playground education and the education most nearly approaching it to-day is that supplied by the playgrounds of America. To that classic demonstration of the educational value of the playground has been added in our day an avalanche of testimony from biology, physiology, anthropology and sociology. Of the $\$ 10,000,000$ playgrounds of Chicago, President Roosevelt says: "They are the greatest civic achievement the world has ever seen." 
To sum up:

First, we do not take care of our children.

Secondly, we need to improve our care along four lines, namely better food, better air, more sunshine, better exercise.

Thirdly, in the very nature of the case, the playground alone can adequately supply the last three of these to the child.

Fourthly, this is no now experiment. We have the classic playground along with classic literature, architecture and art.

Finally, just as we have awakened to the fact that the school provides but a small fraction of a child's education, and that the environment, which includes everything that comes into the child's experience, is teaching him every waking moment of the day (perhaps every sleeping hour of the night, if we agree with Dr. Worcester), so we have come to understand that the activities of the school provide but a small fraction of the exercise necessary for the health of a child in this larger meaning. In the long process of race development, every organ and instinct with which a normal child is born has been tried and found good, has been refined and passed on, and some yet higher function, some yet nobler conduct shall spring from their roots. Not in the school but on the playground can these deep instincts of workmanship, imitation, rivalry, coöperation, find their true and genetic expression and build more stately mansions in the soul as the swift seasons roll. These instincts calling from the deeps of the child's nature are not voices calling him astray, or to delay his upward progress. They are the voices saying to him and to the race:

"Build thee more stately mansions, O my soul, As the swift seasons roll, Leave thy low-vaulted past,

Let each new temple, nobler than the last, Shut thee from Heaven with a dome more vast, Till thou at length art free,

Leaving thine outgrown shell by life's unresting sea." 